\title{
Graded expression of micropearch Paper Graded expression of microRNA-371a-3p in tumor tissues, contralateral testes, and in serum of patients with testicular germ cell tumor
}

\author{
Gazanfer Belge ${ }^{1, *}$, Finja Hennig ${ }^{1, *}$, Cansu Dumlupinar ${ }^{1, *}$, Francesca Grobelny ${ }^{1}$, \\ Klaus Junker ${ }^{2}$, Arlo Radtke ${ }^{1}$ and Klaus-Peter Dieckmann ${ }^{3}$ \\ ${ }^{1}$ Faculty of Biology and Chemistry, University of Bremen, Bremen, Germany \\ ${ }^{2}$ Department of Pathology, Klinikum Bremen-Mitte, Bremen, Germany \\ ${ }^{3}$ Department of Urology, Asklepios Klinik Altona, Hamburg, Germany \\ *These authors contributed equally to this work \\ Correspondence to: Gazanfer Belge, email: belge@uni-bremen.de \\ Keywords: testicular germ cell tumors; microRNA-37la-3p; serum; contralateral testes; in situ hybridization \\ Received: February 11, $2020 \quad$ Accepted: April 03, $2020 \quad$ Published: April 21, 2020 \\ Copyright: Belge et al. This is an open-access article distributed under the terms of the Creative Commons Attribution License 3.0 \\ (CC BY 3.0), which permits unrestricted use, distribution, and reproduction in any medium, provided the original author and source \\ are credited.
}

\section{ABSTRACT}

Background: Serum levels of microRNA-371a-3p represent a specific tumor marker of testicular germ cell tumors (GCTs) but the origin of circulating miR-371a-3p is not finally resolved. The correlation between miR-levels in tissue and serum is unclear.

Results: MiR-levels in GCT tissue are 399-fold higher than in contralateral testicular tissue and 5843-fold higher than in non-testicular tissue. MiR tissue levels correlate with corresponding serum levels $\left(r^{2}=0.181\right)$. ISH detected miR-371a-3p intracellularly in GCT cells except teratoma. A low expression was also detected in normal testicular germ cells.

Conclusions: Circulating miR-371a-3p is specifically derived from GCT tissue. The miR is present in GCT cells except teratoma. A low expression is also found in normal testicular tissue but not in non-testicular tissue. MiR-371a-3p levels in tissue and serum correlate significantly. This study underscores the usefulness of serum miR-371a-3p as tumor marker of GCT.

Patients and methods: Expression levels of miR-371a-3p were concurrently measured in tissues of GCT, contralateral testes $(n=38)$, and in serum $(n=36)$ with real time PCR. For control, 5 healthy testicles and 4 non-testicular tissue samples were examined. MiR-levels were compared using descriptive statistical methods. We also performed in situ hybridization (ISH) of GCT tissue with a probe specific for miR-371a-3p.

\section{INTRODUCTION}

Serum levels of microRNAs (miRs) of the clusters miR-371-373 and miR-302/367 have been suggested as novel biomarkers of testicular germ cell tumors (GCTs) [1-3]. Of the candidate miRs, miR-371a-3p appears to be the most promising serum marker of GCT with a sensitivity of $90.1 \%$ and specificity of $94.1 \%[4,5]$ outperforming the classical markers (alpha fetoprotein, beta human chorionic gonadotropin, lactate dehydrogenase) with their sensitivities of less than $50 \%$ [6]. Apparently, miR-371a-3p features almost all of the qualities a valuable tumor marker is supposed to have [7] since it correlates with clinical stages, and tumor sizes, it highlights response (or non-response) to therapy, and it is present in cases with relapsing GCT suggesting a prominent role of this miR upon follow-up examinations [8-15]. Preliminary data also suggest a possible role of the test upon evaluation of residual masses after chemotherapy $[13,16,17]$. 
While lots of clinical data suggest a strong correlation between tumor burden and miR-371a-3p serum expression, only limited evidence is available to show that serum-based miRs do primarily originate from GCT cells and do not represent any unspecific side reaction of the testis to invasive GCT.

Testicular vein blood sampling had demonstrated that the tumor-bearing testis is most likely the source of circulating miR-371a-3p [18].

Early experiments had provided evidence for the presence of miRs 372-373 in GCT tissue [19]. Later, highthroughput screening and microarray expression profiling documented miRs 371-373 to be present in tissue of GCTs [20-24]. A study using RNA extraction from formalinfixed paraffin embedded GCT tissue again demonstrated the presence of miR-371a-3p in tumor tissue with different expression levels in the various histological subtypes of GCT [25]. All of these studies did not directly compare the miR-expression levels in tumor tissue with corresponding serum levels in the individual patients. The only study to date that evaluated both tissue expression levels and corresponding serum levels did not find a clear correlation between these levels [26].

The aim of the present study was to further clarify the origin of circulating miR-371a-3p by measuring this miR in serum of patients with GCT and concurrently in tissues of the tumor and of the contralateral testes in the same patients. The second goal was to explore if increasing levels of miR371 in GCT tissue would translate into higher serum levels of the miR.

\section{RESULTS}

\section{Results of microRNA expression investigations in tissues}

The median miR-371a-3p expressions in tumor, corresponding contralateral testicular tissue, testicular tissue of healthy controls, and non-testicular tissue of testis-surrounding tunica vaginalis were $\mathrm{RQ}=7,040,480.1$ (IQR 4,713,672.2-13,518,390.0), RQ $=40,974.1$ (IQR 30,119.7-50,549.9), RQ = 37,081.7 (IQR 31,617.2$53,543.4)$, and $\mathrm{RQ}=1,204.9(\mathrm{IQR}=237.5-7,809.9)$ respectively. Thus, the individual miR-371a-3p levels found in tumor tissue are on average 399 -fold higher than those of the corresponding contralateral testicular tissue $(p<0.001)$ (Figures 1, 2). Likewise, expression levels are significantly higher in GCT tissue than in healthy testicular tissue $(p<0.001)$. MiR-371a-3p expression in healthy testicular tissue is not significantly different from that in contralateral testicular tissue $(p=0.985)$. The miR-371a$3 p$ expression in non-testicular tissue (tunica vaginalis) showed 30.8-times lower values than testicular tissue of healthy controls $(p<0.05)$ (Figure 2$)$. In addition, one sample of epididymis was analyzed with the lowest miR371a-3p expression of all tissue samples $(R Q=42.03$ ) (Table 1). There is no difference detectable between the miR-371a-3p expression of seminomas and nonseminomas $(p=0.941)$. Likewise, there is no difference between miR371a-3p expressions in tissues of CS1 and CS $2 / 3$ cases $(p=0.262)$ (Supplementary Figures 1 and 2).

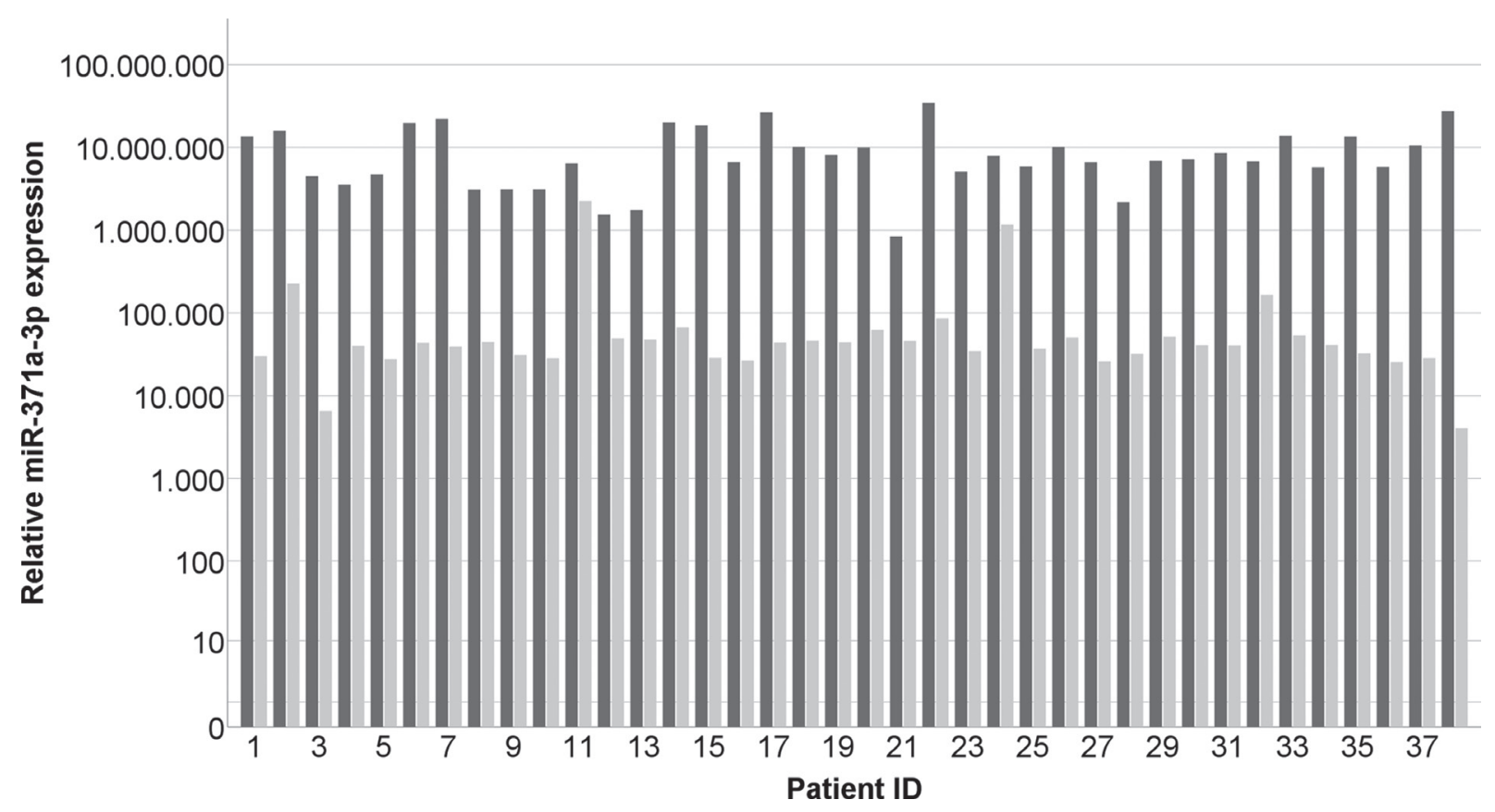

Figure 1: Individual results of measuring miR-371a-3p expressions in GCT tumor tissue samples (dark grey) and the corresponding contralateral testicle (light grey). $n=38$. The patient ID is identical with data sets in Table 1 . The $y$-axis is displayed in a logarithmic scale. 
The ROC analysis based on miR measurements of GCT tissue and the corresponding contralateral tissue in 38 patients revealed an area under the curve of 0.997 . GCT tissue can thus be discriminated from the corresponding contralateral tissue with a diagnostic sensitivity of $100 \%$ and a specificity of $94.7 \%$ (Supplementary Figure 3).

\section{Comparison of miR-371a-3p expression in tissue with serum levels}

MiR-371a-3p expression levels in GCT tissue are significantly higher than corresponding serum levels $(p<0.001)$ (Figure 3$)$. There is a significant positive correlation between tissue levels and those found in serum $(p<0.05)\left(r^{2}=0.181\right)$ (Figure 4A). The correlation is stronger in the sub cohort of CS1 patients $(p<0.05)$ $\left(\mathrm{r}^{2}=0.257\right)$ (Figure 4B) than in cases with CS2 and CS3 where it is not significant $(p>0.05)\left(\mathrm{r}^{2}=9.5 \times 10^{-5}\right)$ (Figure 4C).

\section{Results of in situ hybridization}

Figures 5 and 6 show the ISH results in the various GCT subtypes. The blue stain highlights cells expressing miR-371a-3p intracellularly (Figures 5A, 5B, 6A and 6B). An expression of miR-371a-3p was found in all subtypes of GCT except teratoma (Supplementary Figure 4). Identification of the different subtypes was achieved by additional staining with OCT4 for EC (Figure 5C), PLAP for seminoma (Figure 6C) and Glypican 3 for YST
(Supplementary Figure 4). In contralateral tissue only isolated germ cells showed blue ISH signals.

\section{DISCUSSION}

There are five main results of this study: (1) The miR-371a-3p expression levels are markedly higher in GCT tissue than in the tissue of the contralateral testis and in normal testes, while non-testicular tissue from testissurrounding layers (tunica vaginalis) has even much lower expression. (2) There is clear evidence from ISH studies that miR-371a-3p is localized within GCT tumor cells. (3) The miR expression level in GCT tissue is much higher than in serum. (4) In patients with localized disease (CS1), the GCT tissue miR-levels significantly correlate with the corresponding serum levels. (5) There is a baseline miR$371 \mathrm{a}-3 \mathrm{p}$ expression in tissues of contralateral testes of GCT patients and also in normal testes.

\section{MiR-371a-3p levels in the tissues of tumor and contralateral testis}

A pair-wise comparison of the expression of miR371a-3p in GCT tissue with corresponding contralateral testicular tissue is a unique opportunity to look for the cellular origin of circulating miR-371a-3p molecules. The miR-level in GCT tissue is 399-fold higher than in contralateral testis tissue and the difference between GCT tissue and testicular tissue of control patients is almost the same. This result clearly points to the GCT tissue as the

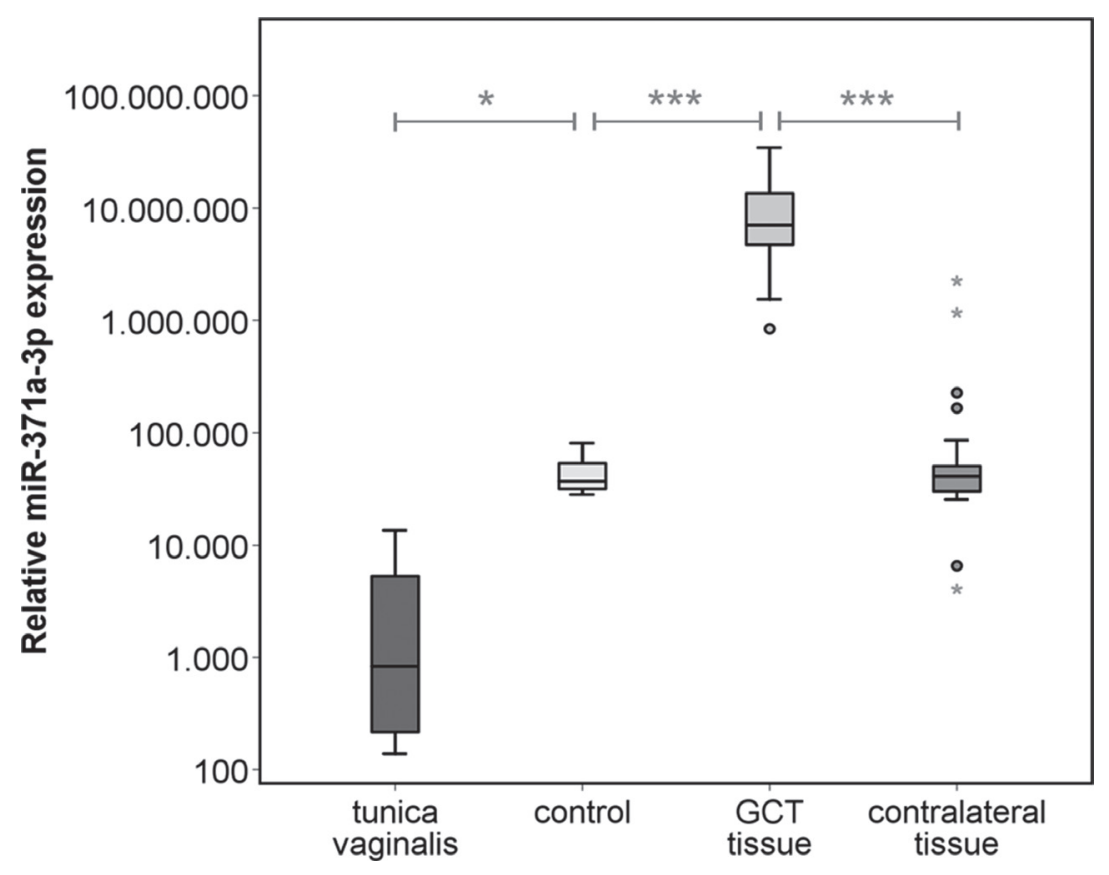

Figure 2: Relative miR-371a-3p expression in GCT tissue $(n=38)$ and corresponding contralateral testicular tissue $(n=38)$ of the same patients, healthy controls $(n=5)$ and non-testicular tissue samples of the tunica vaginalis $(n=4)$. The y-axis is plotted in a logarithmic scale. ${ }^{* * *} p<0.001$. 
Table 1: Clinical data of analyzed patients

\begin{tabular}{|c|c|c|c|c|c|c|}
\hline Patient ID & Age [yrs] & $\begin{array}{c}\text { Diameter } \\
{[\mathrm{mm}]}\end{array}$ & Histology & $\begin{array}{l}\text { Clinical } \\
\text { Stage }\end{array}$ & site & RQ miR-371a-3p \\
\hline \multirow{4}{*}{1} & \multirow{4}{*}{38} & \multirow{3}{*}{46} & \multirow{3}{*}{ Seminoma } & \multirow{3}{*}{ CS2 } & Contralateral tissue & $30,119.70$ \\
\hline & & & & & GCT tissue & $13,518,389.95$ \\
\hline & & & & & Serum & $2,881.17$ \\
\hline & & \multirow{4}{*}{36} & \multirow{3}{*}{ Seminoma } & \multirow{3}{*}{$\mathrm{CS} 1$} & Contralateral tissue & $226,385.18$ \\
\hline \multirow[t]{3}{*}{2} & \multirow[t]{3}{*}{34} & & & & GCT tissue & $15,854,840.19$ \\
\hline & & & & & Serum & $5,509.17$ \\
\hline & & & & & Contralateral tissue & $6,555.18$ \\
\hline \multirow[t]{3}{*}{3} & 38 & 19 & Seminoma & $\mathrm{CS} 1$ & GCT tissue & $4,490,423.24$ \\
\hline & & & & & Serum & 669.09 \\
\hline & & & & & Contralateral tissue & $40,019.62$ \\
\hline 4 & 28 & 31 & Non-Seminoma & $\mathrm{CS} 2$ & GCT tissue & $3,547,619.87$ \\
\hline & & & & & Serum & $6,537.03$ \\
\hline & & & & & Contralateral tissue & $27,715.78$ \\
\hline 5 & 29 & 24 & Non-Seminoma & $\mathrm{CS} 1$ & GCT tissue & $4,713,672.19$ \\
\hline & & & & & Serum & $3,287.19$ \\
\hline & & & & & Contralateral tissue & $43,490.72$ \\
\hline 6 & 36 & 54 & Seminoma & $\mathrm{CS} 1$ & GCT tissue & $19,655,367.47$ \\
\hline & & & & & Serum & $39,571.18$ \\
\hline & & & & & Contralateral tissue & $39,196.03$ \\
\hline 7 & 32 & 42 & Seminoma & $\mathrm{CS} 1$ & GCT tissue & $22,113,437.94$ \\
\hline & & & & & Serum & $41,500.32$ \\
\hline & & & & & Contralateral tissue & $44,404.55$ \\
\hline 8 & 51 & 18 & Seminoma & $\mathrm{CS} 1$ & GCT tissue & $3,088,382.47$ \\
\hline & & & & & Serum & $1,096.01$ \\
\hline & & & & & Contralateral tissue & $31,181.87$ \\
\hline 9 & 45 & 67 & Seminoma & $\mathrm{CS} 1$ & GCT tissue & $3,109,863.87$ \\
\hline & & & & & Serum & $7,068.64$ \\
\hline & & & & & Contralateral tissue & $28,494.98$ \\
\hline 10 & 41 & 45 & Seminoma & $\mathrm{CS} 1$ & GCT tissue & $3,109,863.87$ \\
\hline & & & & & Serum & $6,313.85$ \\
\hline 11 & 25 & 26 & Seminoma & & Contralateral tissue & $2,245,211.62$ \\
\hline 11 & 25 & 26 & Seminoma & CSI & GCT tissue & $6,439,065.97$ \\
\hline & & & & & Contralateral tissue & $49,612.64$ \\
\hline 12 & 36 & 31 & Seminoma & $\mathrm{CS} 1$ & GCT tissue & $1,544,191.24$ \\
\hline & & & & & Serum & $2,131.85$ \\
\hline & & & & & Contralateral tissue & $47,922.65$ \\
\hline 13 & 40 & 37 & Seminoma & $\mathrm{CS} 1$ & GCT tissue & $1,749,389.37$ \\
\hline & & & & & Serum & $10,019.87$ \\
\hline & & & & & Contralateral tissue & $66,839.81$ \\
\hline 14 & 27 & 41 & Non-Seminoma & $\mathrm{CS} 1$ & GCT tissue & $19,929,746.17$ \\
\hline & & & & & Serum & $120,356.55$ \\
\hline & & & & & Contralateral tissue & $28,693.18$ \\
\hline 15 & 36 & 33 & Non-Seminoma & $\mathrm{CS} 1$ & GCT tissue & $18,466,664.88$ \\
\hline & & & & & Serum & $4,629.83$ \\
\hline & & & & & Contralateral tissue & $26,586.75$ \\
\hline 16 & 37 & 52 & Non-Seminoma & $\mathrm{CS} 1$ & GCT tissue & $6,620,092.75$ \\
\hline & & & & & Serum & $40,760.69$ \\
\hline & & & & & Contralateral tissue & $43,793.22$ \\
\hline 17 & 30 & 22 & Seminoma & $\mathrm{CS} 2$ & GCT tissue & $26,480,371.01$ \\
\hline & & & & & Serum & $2,652.53$ \\
\hline & & & & & Contralateral tissue & $46,290.23$ \\
\hline 18 & 34 & 73 & Seminoma & $\mathrm{CS} 3$ & GCT tissue & $10,103,977.53$ \\
\hline & & & & & Serum & $56,414.42$ \\
\hline & & & & & Contralateral tissue & $44,036.74$ \\
\hline 19 & 31 & 68 & Seminoma & $\mathrm{CS} 1$ & GCT tissue & $8,110,840.54$ \\
\hline & & & & & Serum & $4,772.14$ \\
\hline & & & & & Contralateral tissue & $62,623.65$ \\
\hline 20 & 49 & 18 & Seminoma & $\mathrm{CS} 1$ & GCT tissue & $9,930,397.24$ \\
\hline & & & & & Serum & 288.5 \\
\hline & & & & & Contralateral tissue & $46,002.35$ \\
\hline 21 & 47 & 30 & Seminoma & $\mathrm{CS} 1$ & GCT tissue & $841,392.83$ \\
\hline & & & & & Serum & 100.78 \\
\hline & & & & & Contralateral tissue & $85,902.95$ \\
\hline 22 & 34 & 34 & Seminoma & $\mathrm{CS} 1$ & GCT tissue & $34,412,276.52$ \\
\hline & & & & & Serum & $16,913.42$ \\
\hline & & & & & Contralateral tissue & $34,646.45$ \\
\hline 23 & 34 & 33 & Seminoma & $\mathrm{CS} 1$ & GCT tissue & $5,083,603.22$ \\
\hline & & & & & Serum & 469.32 \\
\hline
\end{tabular}




\begin{tabular}{|c|c|c|c|c|c|c|}
\hline \multirow{4}{*}{24} & & & & & Contralateral tissue & $1,167,847.12$ \\
\hline & 38 & 50 & Non-Seminoma & $\mathrm{CS} 3$ & GCT tissue & $7,899,993.31$ \\
\hline & & & & & Serum & $4,434.08$ \\
\hline & & & & & Contralateral tissue & $37,210.44$ \\
\hline \multirow[t]{3}{*}{25} & 34 & 11 & Seminoma & CS1 & GCT tissue & $5,859,800.02$ \\
\hline & & & & & Serum & 290.67 \\
\hline & & & & & Contralateral tissue & $50,549.88$ \\
\hline \multirow[t]{3}{*}{26} & 35 & 75 & Seminoma & CS2 & GCT tissue & $10,076,002.16$ \\
\hline & & & & & Serum & $3,402.60$ \\
\hline & & & & & Contralateral tissue & $25,931.54$ \\
\hline \multirow[t]{3}{*}{27} & 31 & n. a. & Non-Seminoma & CS2 & GCT tissue & $6,601,763.38$ \\
\hline & & & & & Serum & 32,461 \\
\hline & & & & & Contralateral tissue & $32,214.44$ \\
\hline \multirow[t]{3}{*}{28} & 41 & 6 & Seminoma & CS1 & GCT tissue & $2,191,397.85$ \\
\hline & & & & & Serum & 445.85 \\
\hline & & & & & Contralateral tissue & $51,647.83$ \\
\hline \multirow[t]{2}{*}{29} & 66 & 29 & Seminoma & $\mathrm{CS} 2$ & GCT tissue & $6,891,659.54$ \\
\hline & & & & & Serum & $2,007.83$ \\
\hline \multirow{3}{*}{30} & 53 & 42 & Seminoma & CS1 1 & Contralateral tissue & $40,860.52$ \\
\hline & 53 & 42 & seminoma & $\operatorname{csi}$ & GCT tissue & $7,189,300.62$ \\
\hline & & & & & Contralateral tissue & $40,550.16$ \\
\hline \multirow[t]{3}{*}{31} & 47 & 37 & Seminoma & $\mathrm{CS} 2$ & GCT tissue & $8,585,198.14$ \\
\hline & & & & & Serum & 231.91 \\
\hline & & & & & Contralateral tissue & $166,068.62$ \\
\hline \multirow[t]{3}{*}{32} & 52 & 48 & Seminoma & CS1 & GCT tissue & $6,777,961.45$ \\
\hline & & & & & Serum & 840.1 \\
\hline & & & & & Contralateral tissue & $53,692.02$ \\
\hline \multirow[t]{3}{*}{33} & 40 & 56 & Seminoma & CS1 & GCT tissue & $13,792,876.25$ \\
\hline & & & & & Serum & $4,638.43$ \\
\hline & & & & & Contralateral tissue & $41,087.73$ \\
\hline \multirow[t]{3}{*}{34} & 30 & 45 & Non-Seminoma & CS2 & GCT tissue & $5,743,186.58$ \\
\hline & & & & & Serum & $11,405.33$ \\
\hline & & & & & Contralateral tissue & $32,709.45$ \\
\hline \multirow[t]{3}{*}{35} & 47 & 14 & Non-Seminoma & CS1 & GCT tissue & $13,499,662.47$ \\
\hline & & & & & Serum & 516.07 \\
\hline & & & & & Contralateral tissue & $25,468.39$ \\
\hline \multirow[t]{3}{*}{36} & 34 & 47 & Seminoma & CS1 & GCT tissue & $5,799,190.10$ \\
\hline & & & & & Serum & $9,597.35$ \\
\hline & & & & & Contralateral tissue & $28,593.90$ \\
\hline \multirow[t]{3}{*}{37} & 51 & 22 & Seminoma & CS1 & GCT tissue & $10,547,662.66$ \\
\hline & & & & & Serum & $3,634.19$ \\
\hline & & & & & Contralateral tissue & $4,060.44$ \\
\hline \multirow[t]{2}{*}{38} & 47 & 16 & Seminoma & CS2 & GCT tissue & $27,376,221.46$ \\
\hline & & & & & Serum & $18,247.61$ \\
\hline 39 & 47 & 0 & Control & normal & Control & $31,617.16$ \\
\hline 40 & 63 & 0 & Control & normal & Control & $53,543.36$ \\
\hline 41 & 19 & 0 & Control & normal & Control & $37,081.71$ \\
\hline 42 & 60 & 0 & Control & normal & Control & $28,298.15$ \\
\hline 43 & 54 & 0 & Control & normal & Control & $81,156.55$ \\
\hline 44 & 78 & 0 & Control & normal & Tunica vaginalis & 138.88 \\
\hline 45 & 20 & 0 & Control & normal & Tunica vaginalis & 336.12 \\
\hline 46 & 52 & 0 & Control & normal & Tunica vaginalis & 42.03 \\
\hline 47 & 33 & 0 & Control & normal & Tunica vaginalis & $13,546.11$ \\
\hline 48 & 46 & 0 & Control & normal & Epididymis & $2,073.66$ \\
\hline
\end{tabular}

Abbreviations: CS: Clinical stage, GCT: Germ cell tumor, mm: millimeter, RQ: Relative quantity, yrs: Years.

source of circulating miR-371a-3p. Previous reports had already pointed to the presence of the miR-371-373 cluster in GCT tissue, without quantitative measurements [20], [21]. Our result is consistent with data from measuring the miR in testicular vein blood where a 195 -fold higher level was found than in systemic circulation [18]. The present finding of a base-line expression of miR-371a-3p in contralateral testis tissue and in healthy testicular tissue mirrors the finding of a 4-fold higher miR-expression in testicular vein blood compared to peripheral blood in healthy males [18]. These data suggest the presence of this particular miR even in normal testicular tissue though in low quantity and not exclusively in GCT tissue. This assumption is supported by the findings of Boellaard et al. who recently documented the presence of miR-371a-3p in normal testicular tissue and its absence in other parts of the urogenital tract [27]. As miR-371 has been shown to be specifically associated with human stem cells [28-30] and as it is found in seminal plasma, too [31,32], it is rational to assume that this miR is specifically generated by normal testicular germ cells and most probably even more by the cells of GCT. 


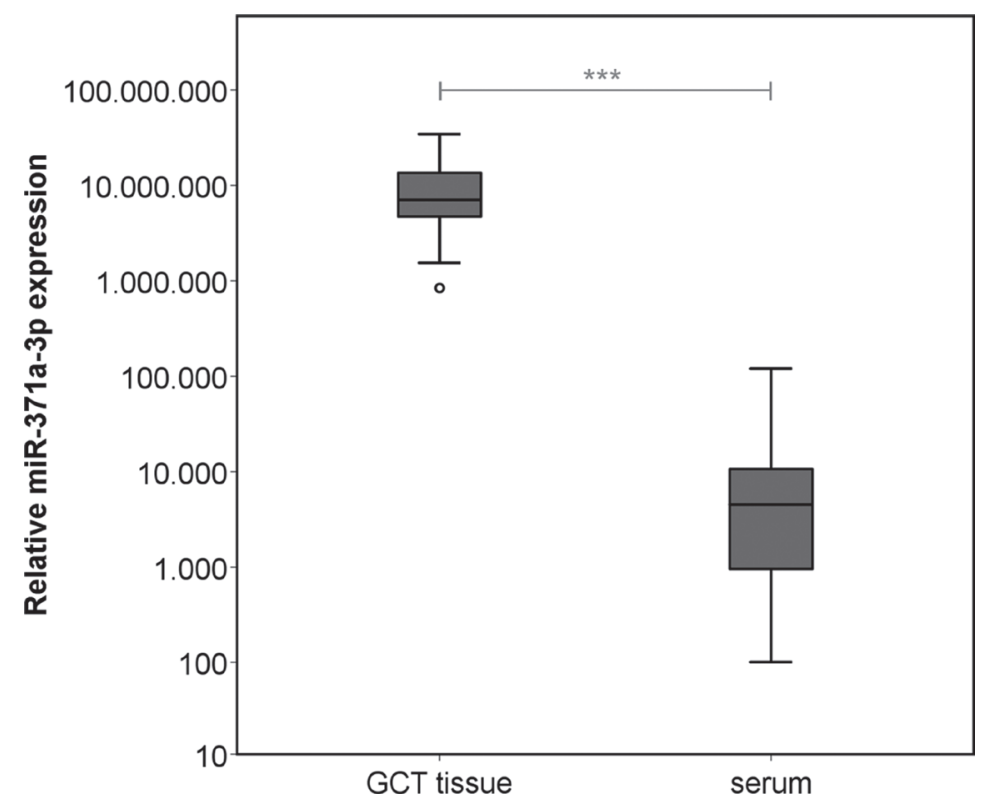

Figure 3: Relative miR-371a-3p expression in GCT tissue $(n=38)$ and corresponding preoperative serum samples of the same patients $(\boldsymbol{n}=\mathbf{3 6})$. The y-axis is plotted in a logarithmic scale. ${ }^{* * *} p<0.001$.
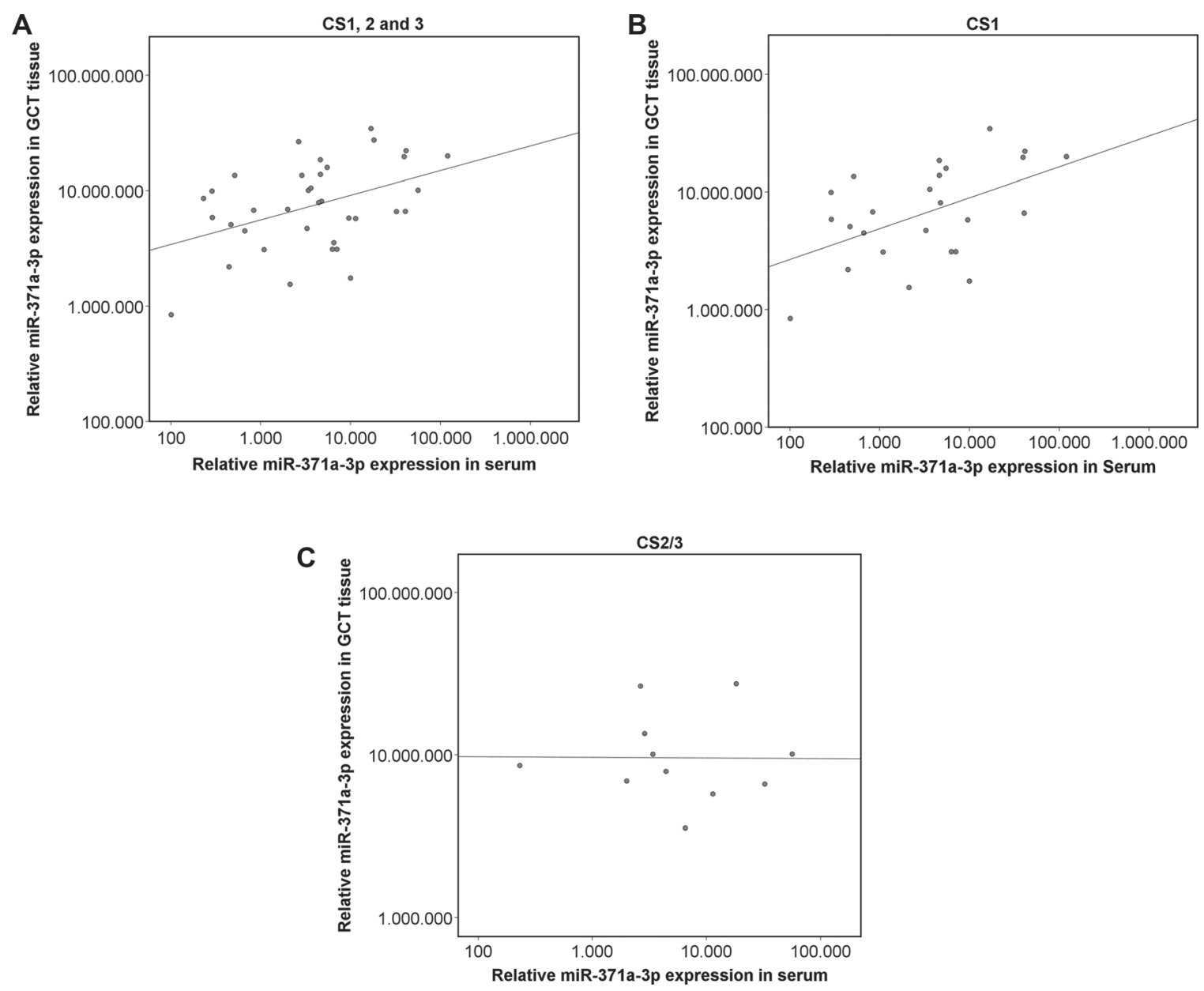

Figure 4: Scatterplot of the relative miR-371a-3p expression in GCT tissue and corresponding serum levels. The axes in all parts are depicted in a logarithmic scale. (A) Entire GCT cohort $(n=36)(p \leq 0.05)\left(\mathrm{r}^{2}=0.181\right)$. (B) Only CS1 patients $(n=25 ; p \leq 0.05)$ $\left(\mathrm{r}^{2}=0.257\right)$. (C) Only CS2/3 patients $(n=11 ; p \geq 0.05)\left(\mathrm{r}^{2}=9.5 \times 10^{-5}\right)$. 


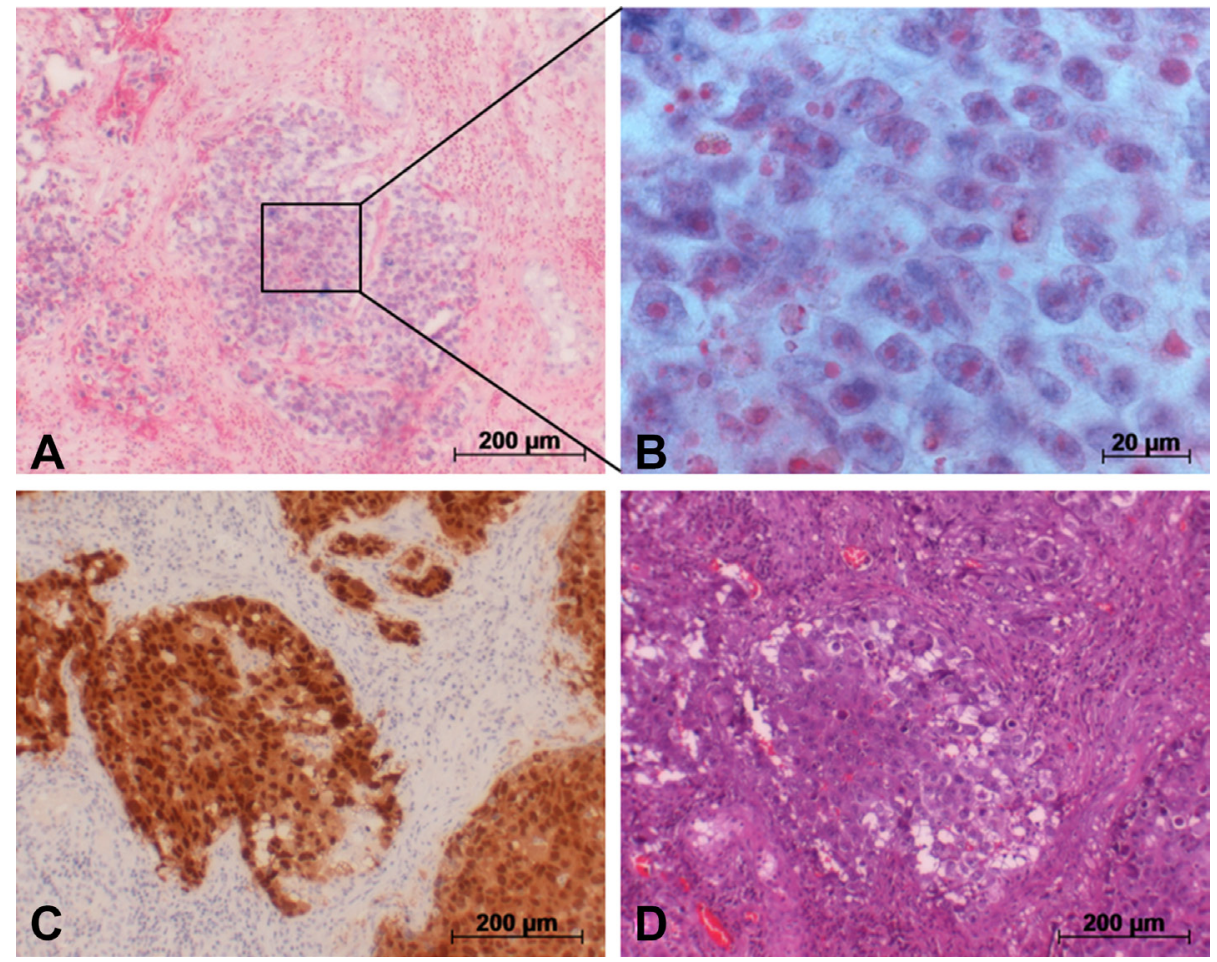

Figure 5: Detection of miR-371a-3p in GCT tumor (EC) via in situ hybridization. (A) In situ hybridization with a probe against miR-371a-3p causes blue staining in cells. (B) Section from A. (C) Immunohistochemical staining of the same area with an OCT4 antibody for identification of EC cells. (D) H\&E staining of the same area.

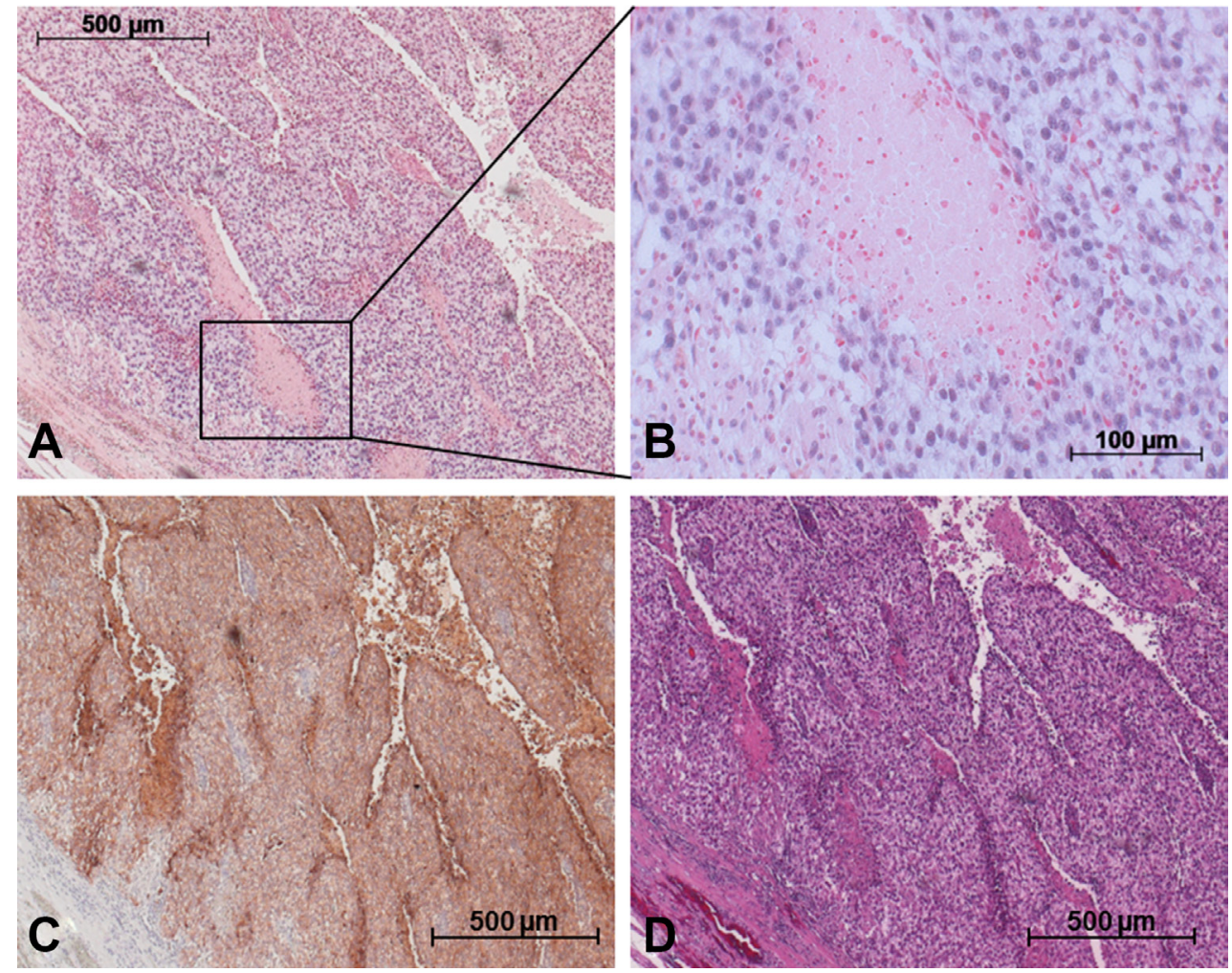

Figure 6: Detection of miR-371a-3p in GCT mixed tumor including SE and YST via in situ hybridization. (A) In situ hybridization with a probe against miR-371a-3p causes blue staining in cells. (B) Section from A. (C) Immunohistochemical staining of the same area with PLAP antibody for identification of SE cells. (D) H\&E staining of the same area. 
In serum, patients with nonseminomas showed significantly higher miR-371a-3p expression, and CS2/3 patients had higher levels than those with CS1 [5]. In tissue no difference was detectable between the miR$371 \mathrm{a}-3 \mathrm{p}$ expression of seminomas and nonseminomas nor between tissues of CS1 and CS 2/3 cases. Yet, these results should be interpreted with caution as only a small patient collective was examined.

\section{Intracellular localization of miR-371a-3p by ISH}

In situ hybridization clearly demonstrated microRNA-371-3p to be localized intracellularly in the cells of GCT. Thus, the ISH experiments morphologically supplement the data obtained by measuring the miR in homogenized GCT tissue.

In conjunction with previous reports on the presence of the miR-371-373 cluster in GCT tissue [20, 21, 25, 33] there is now ample evidence for the origin of circulating miR-371a-3p from testicular tumor cells.

Of note, all subtypes of GCT except teratoma stained positive for the miR-371a-3p probe. The absence of miR-371a-p staining in teratoma cells is consistent with the non-expression of this miR in serum of GCT patients $[4,5,16]$. Likewise, in an evaluation of miR371a-3p expression levels in GCT subtypes by RNA extraction from formalin fixed paraffin embedded orchiectomy specimens, Vilela-Salgueiro et al. revealed a strong expression in all GCT subtypes except teratoma [25]. The reason for the non-expression of the miR by teratoma is probably related to the analogies of GCT biology and the human embryonal development $[34,35]$. While most of the GCT subtypes mimic early developmental stages of embryonal development and accordingly retain their biochemical characteristics including the microRNA profile of stem cells, the teratoma subtype represents a more advanced and more mature histological subtype that has lost all of the biochemical characteristics of stem cells particularly the typical expression of miR-371a-3p [36].

\section{Correlation of miR-expression levels in tissue with serum levels}

Systematic paired measurements of miR-expression levels in GCT tissue and corresponding serum levels had not been reported so far. One early pilot study had indicated that miR-expression levels of tissue and serum do not correlate [24]. However, the present systematic analysis of 36 patients revealed a significant correlation of the expression levels of the two compartments. It is of note that this correlation was not significant in cases with clinical stages CS2 and 3. As in advanced clinical stages the marker substance is released from both the primary tumor and metastatic seeds it is rational that the correlation of tissue expression with serum levels is only significant in cases confined to the testis. The serum level of circulating miR-371a-3p is obviously a product of the number of miR-producing tumor cells (tumor bulk) as shown previously [5] and of the specific secreting capacity of the individual GCT as shown herein. Most probably, additional biological determinants e. g. direct vascular invasion of the tumor and other hitherto unknown factors do also affect the serum level of miR-371a-3p.

In all, the present evaluation confirms the understanding that circulating miR-371a-3p-are specifically derived from cells of testicular germ cell neoplasms.

This miR, thus represents a specific tumor marker for GCTs, which is not expressed in other diseases. By contrast, the specificity of the classical tumor marker AFP is considerably hampered by its association with non-GCT related conditions, such as liver diseases [37].

\section{MATERIALS AND METHODS}

\section{Patients for tissue and serum investigations}

Preoperative serum samples and corresponding tissue specimens were collected from patients (median age 36.5) undergoing surgery for testicular tumor. GCT tissue was taken from 38 orchiectomy specimens, and contralateral testis tissue was taken from corresponding contralateral biopsy specimens. This surgical procedure was routinely performed on all patients with suspected testis tumor to look for Germ cell neoplasia in situ (GCNis) according to institutional guide-lines. None of the patients enrolled in this study had contralateral GCNis. All tissue specimens were kept frozen at $-80^{\circ} \mathrm{C}$ under further processing. Histologically, the GCT tissue specimens consisted of 29 seminomas and nine nonseminomas. Clinically, 27 patients had clinical stage 1 (CS1) and eleven CS 2 and 3 (CS2/3). Preoperative serum samples were obtained from 36 of the 38 patients. For control, testicular tissue was obtained from five men without GCT undergoing orchiectomy for epididymitis. Furthermore, four samples of testis surrounding tunica vaginalis and one specimen of the epididymis were analyzed. All patients had given informed consent prior to surgery. Ethical approval of the study was provided by Ärztekammer Bremen (reference No 301, 2011). All study activities had been conducted according to the Declaration of Helsinki of the World Medical Association (as amended by the 64th General Assembly, 2013). Individual data of the patients and controls are listed in Table 1.

\section{Patients for histological investigation of presence of microRNAs in GCT cells}

Formalin-fixed paraffin-embedded (FFPE) samples of six patients with testicular GCTs were analyzed by immunohistochemistry and in situ hybridization (ISH) to look for the presence of miR-371a-3p in tumor tissue. Histologically, the GCTs comprised of three mixed nonseminomatous tumors (embryonal carcinoma, yolk sac 
tumor, and chorio carcinoma), one pure seminoma, one pure embryonal carcinoma and one teratoma. In addition, one tissue specimen of a contralateral testis was analyzed.

\section{Extraction and measurement of miRNAs}

Tumor and contralateral testis tissue (10-50 mg) was homogenized in $1000 \mu \mathrm{L}$ TRIzol ${ }^{\circledR}$ Reagent following the manufacturer's instructions (Fisher Scientific, Schwerte, Germany) using a TissueLyser (Qiagen, Hilden, Germany) with $5 \mathrm{~mm}$ steel beads for $10 \mathrm{~min}$ at $30 \mathrm{~Hz}$. The extracted RNA was resuspended in $50 \mu 1$ nuclease-free water.

For the measurement of miR-371a-3p levels, RNA was isolated from $200 \mu \mathrm{L}$ Serum using the miRNeasy mini Kit (Qiagen, Hilden, Germany) according to the manufacturer's description. Reverse transcription (RT) was performed with $10-20 \mathrm{ng} / \mu \mathrm{L}$ RNA isolated from tissue and $6 \mu \mathrm{L}$ RNA isolated from Serum, using the TaqMan MicroRNA Reverse Transcription Kit (Applied Biosystems, Darmstadt, Germany). Standard PCR was carried out for preamplification of the cDNA with TaqMan Assays for miR-371a-3p (assay ID 002124) and the endogenous control miR-93-5p (assay ID 000432) in a 1:100 dilution. Measurement of the miRNA expression was performed with quantitative real-time PCR (RTqPCR) on a 7500 Fast Real-Time PCR System (Applied Biosystems, Darmstadt, Germany) using FAST Start Universal Probe Master (Roche Diagnostics, Mannheim, Germany) and the undiluted TaqMan Assays. The relative quantity (RQ) was calculated using the $2^{-\Delta \Delta C T}$-method [38].

\section{Immunohistochemistry}

For morphological identification of the histological type of GCTs sections of $5 \mu \mathrm{m}$ of FFPE-blocks were analyzed with hematoxylin and eosin stain (H\&E stain), OCT4, PLAP and glypican 3. Staining with hematoxylin and eosin with standard histological techniques were used to distinguish between tumor-free areas and tumor tissue. OCT4 staining for identification of embryonal carcinomas (EC), PLAP staining for seminomas (SE) and glypican 3 for yolk-sac tumors (YST) (Diagnostic BioSystems, Pleasanton, CA, USA) were then conducted according to institutional standard operating procedures [39, 40].

\section{MicroRNA in situ hybridization}

After immunohistochemical identification of the particular GCT-subtypes, the corresponding tumor sections were subsequently processed for in situ hybridization (ISH) with a miRCURY LNA probe (Exiqon, Vedbaek, Denmark; probe ID 38555-15) specific for miR-371a-3p. The protocol was performed according to the manufacturer's instructions using a proteinase-K concentration of $15 \mu \mathrm{g} / \mathrm{ml}$, a hybridization temperature of $51^{\circ} \mathrm{C}$ and a probe concentration of $80 \mathrm{nM}$. Microscopic evaluations were performed on an Axioskop 2 plus microscope (Zeiss, Göttingen, Germany). Histological findings were documented using the AxioCam HRc digital camera (Zeiss, Göttingen, Germany) and then edited with AxioVision Software v.4.8 (Zeiss, Göttingen, Germany). Presence of miR-371a-3p within GCTs was defined by distinct blue staining of the cells, and accordingly, only these cells were considered miR-371a-3p positive. Only the presence or absence of the miR-371a-3p in the specimen was evaluated, no quantification was attempted.

\section{Statistical methods}

The Wilcoxon signed rank test was used for comparison of dependent subgroups. The Mann-Whitney $\mathrm{U}$ test was used to compare median miRNA expressions among the various subgroups. Receiver Operating characteristics (ROC) curves were calculated to analyze the sensitivity and specificity of tissue miR-levels to distinguish GCT tissue from non-tumorous tissue. Spearman's rank correlation coefficient was calculated to determine correlations. All tests were two-sided and significance was assumed at $p<0.05$. Statistical analysis was performed using SPSS version 24 (IBM, Armonk, NY, USA).

\section{LIMITATIONS}

The results of the present study rest on 36 patients only, thus the statistical power is still limited. With respect to sample processing, the time for transfer of the tissue specimens from operation site to the laboratory i. e. the time-interval until conservation in the freezer $\left(-80^{\circ} \mathrm{C}\right)$ varied from 12 hours to 36 hours depending on the conditions of surface mail. Thus, deterioration of some samples during transfer cannot entirely be excluded. We could not correlate the miR-measurements in contralateral testicular tissue specimens with the quality of spermatogenesis because these data were not available.

\section{CONCLUSIONS}

The present study provides much of evidence for the understanding that circulating miR-371a-3p molecules are specifically derived from testicular GCT cells. The inability of teratoma cells to produce miR$371 a-3 p$ is confirmed on the tissue level. There is a significant correlation of the miR-expression levels in GCT tissue with corresponding serum levels. Normal testicular tissue displays a low baseline expression of miR-371a-3p pointing to the role of the miR in human stem cells.

\section{Abbreviations}

AFP: Alpha fetoprotein; bHCG: Beta human chorionic gonadotropin; CS: Clinical stage; EC: Embryonal 
carcinomas; FFPE: Formalin-fixed paraffin-embedded; GCNis: Germ cell neoplasia in situ; GCT: Germ cell tumor; H\&E: Hematoxylin and eosin; IQR: Inter quartile range; ISH: In situ hybridization; LDH: Lactate dehydrogenase; miR: micro RNA; M371: miR-371a-3p; OCT4: Octamerbinding transcription factor 4; PLAP: Placental alkaline phosphatase; qPCR: Quantitative real-time PCR; RT: Reverse transcription; ROC: Receiver operating characteristics; RQ: Relative quantity; SE: Seminoma; SPSS: Statistical package for the social sciences; YST: Yolk-sac tumor.

\section{Author contributions}

GB, FH, CD, AR, KPD designed the study; KPD patient enrolment; FH, CD, FG executed the experiments; $\mathrm{GB}, \mathrm{FH}, \mathrm{CD}, \mathrm{KJ}, \mathrm{AR}, \mathrm{KPD}$ analysis and interpretation of the data; FH, AR, FG statistical analysis; GB, FH, CD, AR, KPD drafting of manuscript. All authors critically revised and finally approved the manuscript.

\section{ACKNOWLEDGMENTS}

The authors are grateful to Svenja Mende, Svea Riek, Verena Nickel, University of Bremen and laboratory staff members of Albertinen Krankenhaus Hamburg and Asklepios Klinik Altona, Hamburg, for technical assistance during processing of serum samples.

\section{CONFLICTS OF INTEREST}

Gazanfer Belge and Klaus-Peter Dieckmann each possess 9.7\% ownership shares of miRdetect $\mathrm{GmbH}$, Bremen, a start-up company aiming to develop a commercially available test for measuring microRNAs in serum. MiRdetect holds a patent for the measurement of miRNA in body fluids at the limit of detection. All other authors declare no competing interests towards this report.

A further patent for the use of miR-371a-3p as a marker for GCNis was filed by miRdetect/University of Bremen on November, 2nd 2016.

Arlo Radtke is an employee of miRdetect $\mathrm{GmbH}$, Bremen since January 2019.

\section{FUNDING}

This study was supported by Albertinen-Stiftung Hamburg $(1-3,2015)$.

\section{REFERENCES}

1. Belge G, Dieckmann KP, Spiekermann M, Balks T, Bullerdiek J. Serum levels of microRNAs miR-3713: a novel class of serum biomarkers for testicular germ cell tumors? Eur Urol. 2012; 61:1068-69. https://doi. org/10.1016/j.eururo.2012.02.037. [PubMed]
2. Murray MJ, Huddart RA, Coleman N. The present and future of serum diagnostic tests for testicular germ cell tumours. Nat Rev Urol. 2016; 13:715-25. https://doi. org/10.1038/nrurol.2016.170. [PubMed]

3. Lobo J, Gillis AJ, van den Berg A, Dorssers LC, Belge G, Dieckmann KP, Roest HP, van der Laan LJ, Gietema J, Hamilton RJ, Jerónimo C, Henrique R, Salvatori D, Looijenga LH. Identification and Validation Model for Informative Liquid Biopsy-Based microRNA Biomarkers: Insights from Germ Cell Tumor In Vitro, In Vivo and Patient-Derived Data. Cells. 2019; 8:1637. https://doi. org/10.3390/cells8121637. [PubMed]

4. van Agthoven T, Looijenga LH. Accurate primary germ cell cancer diagnosis using serum based microRNA detection (ampTSmiR test). Oncotarget. 2016; 8:58037-49. https:// doi.org/10.18632/oncotarget.10867. [PubMed]

5. Dieckmann KP, Radtke A, Geczi L, Matthies C, Anheuser P, Eckardt U, Sommer J, Zengerling F, Trenti E, Pichler R, Belz H, Zastrow S, Winter A, et al. Serum levels of microRNA-371a-3p (M371 Test) as a new biomarker of testicular germ cell-tumors: results of a prospective multicentric study. J Clin Oncol. 2019; 37:1412-23. https:// doi.org/10.1200/JCO.18.01480. [ubMed]

6. Dieckmann KP, Simonsen-Richter H, Kulejewski M, Anheuser P, Zecha H, Isbarn H, Pichlmeier U. Serum Tumour Markers in Testicular Germ Cell Tumours: Frequencies of Elevated Levels and Extents of Marker Elevation Are Significantly Associated with Clinical Parameters and with Response to Treatment. BioMed Res Int. 2019; 2019:5030349. https://doi. org/10.1155/2019/5030349. [PubMed]

7. Lange PH, Winfield HN. Biological markers in urologic cancer. Cancer. 1987; 60:464-72. [PubMed]

8. van Agthoven T, Eijkenboom WM, Looijenga LH. microRNA-371a-3p as informative biomarker for the follow-up of testicular germ cell cancer patients. Cell Oncol (Dordr). 2017; 40:379-88. https://doi.org/10.1007/s13402017-0333-9. [PubMed]

9. Radtke A, Cremers JF, Kliesch S, Riek S, Junker K, Mohamed SA, Anheuser P, Belge G, Dieckmann KP. Can germ cell neoplasia in situ be diagnosed by measuring serum levels of microRNA371a-3p? J Cancer Res Clin Oncol. 2017; 143:2383-92. https://doi.org/10.1007/s00432017-2490-7. [PubMed]

10. Radtke A, Hennig F, Ikogho R, Hammel J, Anheuser P, Wülfing C, Belge G, Dieckmann KP. The Novel Biomarker of Germ Cell Tumours, Micro-RNA-371a-3p, Has a Very Rapid Decay in Patients with Clinical Stage 1. Urol Int. 2018; 100:470-75. https://doi.org/10.1159/000488771. [PubMed]

11. Mego M, van Agthoven T, Gronesova P, Chovanec M, Miskovska V, Mardiak J, Looijenga LH. Clinical utility of plasma miR-371a-3p in germ cell tumors. J Cell Mol Med. 2019; 23:1128-36. https://doi.org/10.1111/jcmm.14013. [PubMed] 
12. Terbuch A, Adiprasito JB, Stiegelbauer V, Seles M, Klec C, Pichler GP, Resel M, Posch F, Lembeck AL, Stöger H, Szkandera J, Pummer K, Bauernhofer T, et al. MiR-371a-3p Serum Levels Are Increased in Recurrence of Testicular Germ Cell Tumor Patients. Int J Mol Sci. 2018; 19:3130. https://doi.org/10.3390/ijms19103130. [

13. Rosas Plaza $X$, van Agthoven T, Meijer C, van Vugt MA, de Jong S, Gietema JA, Looijenga LH. miR-371a-3p, miR-373-3p and miR-367-3p as Serum Biomarkers in Metastatic Testicular Germ Cell Cancers Before, During and After Chemotherapy. Cells. 2019; 8:E1221. https://doi. org/10.3390/cells8101221. [PubMed]

14. Nappi L, Thi M, Lum A, Huntsman D, Eigl BJ, Martin C, O’Neil B, Maughan BL, Chi K, So A, Black PC, Gleave M, Wyatt AW, et al. Developing a Highly Specific Biomarker for Germ Cell Malignancies: Plasma miR371 Expression Across the Germ Cell Malignancy Spectrum. J Clin Oncol. 2019; 37:3090-98. https://doi.org/10.1200/JCO.18.02057. [PubMed]

15. Anheuser P, Radtke A, Wülfing C, Kranz J, Belge G, Dieckmann KP. Serum Levels of MicroRNA371a-3p: A Highly Sensitive Tool for Diagnosing and Staging Testicular Germ Cell Tumours: A Clinical Case Series. Urol Int. 2017; 99:98-103. https://doi.org/10.1159/000477446. [PubMed]

16. Leão R, van Agthoven T, Figueiredo A, Jewett MA, Fadaak $\mathrm{K}$, Sweet J, Ahmad AE, Anson-Cartwright L, Chung P, Hansen A, Warde P, Castelo-Branco P, O'Malley M, et al. Serum miRNA Predicts Viable Disease after Chemotherapy in Patients with Testicular Nonseminoma Germ Cell Tumor. J Urol. 2018; 200:126-35. https://doi.org/10.1016/j. juro.2018.02.068. [PubMed]

17. Lafin JT, Singla N, Woldu SL, Lotan Y, Lewis CM, Majmudar K, Savelyeva A, Kapur P, Margulis V, Strand DW, Murray MJ, Amatruda JF, Bagrodia A. Serum MicroRNA-371a-3p Levels Predict Viable Germ Cell Tumor in Chemotherapy-naïve Patients Undergoing Retroperitoneal Lymph Node Dissection. Eur Urol. 2020; 77:290-92. https://doi.org/10.1016/j.eururo.2019.10.005. [PubMed]

18. Dieckmann KP, Spiekermann M, Balks T, Ikogho R, Anheuser P, Wosniok W, Loening T, Bullerdiek J, Belge G. MicroRNA miR-371a-3p - a novel serum biomarker of testicular germ cell tumors: evidence for specificity from measurements in testicular vein blood and in neoplastic hydrocele fluid. Urol Int. 2016; 97:76-83. https://doi. org/10.1159/000444303. [PubMed]

19. Voorhoeve PM, le Sage C, Schrier M, Gillis AJ, Stoop H, Nagel R, Liu YP, van Duijse J, Drost J, Griekspoor A, Zlotorynski E, Yabuta N, De Vita G, et al. A genetic screen implicates miRNA-372 and miRNA-373 as oncogenes in testicular germ cell tumors. Cell. 2006; 124:1169-81. https://doi.org/10.1016/j.cell.2006.02.037. [PubMed]

20. Gillis AJ, Stoop HJ, Hersmus R, Oosterhuis JW, Sun Y, Chen C, Guenther S, Sherlock J, Veltman I, Baeten J, van der Spek PJ, de Alarcon P, Looijenga LH. High-throughput
microRNAome analysis in human germ cell tumours. J Pathol. 2007; 213:319-28. https://doi.org/10.1002/ path.2230. [PubMed]

21. Palmer RD, Murray MJ, Saini HK, van Dongen S, AbreuGoodger C, Muralidhar B, Pett MR, Thornton CM, Nicholson JC, Enright AJ, Coleman N, and Children's Cancer and Leukaemia Group. Malignant germ cell tumors display common microRNA profiles resulting in global changes in expression of messenger RNA targets. Cancer Res. 2010; 70:2911-23. https://doi.org/10.1158/0008-5472. CAN-09-3301. [PubMed]

22. Shen H, Shih J, Hollern DP, Wang L, Bowlby R, Tickoo SK, Thorsson V, Mungall AJ, Newton Y, Hegde AM, Armenia J, Sánchez-Vega F, Pluta J, et al, and Cancer Genome Atlas Research Network. Integrated Molecular Characterization of Testicular Germ Cell Tumors. Cell Rep. 2018; 23:3392406. $\quad$ https://doi.org/10.1016/j.celrep.2018.05.039. [PubMed]

23. Novotny GW, Belling KC, Bramsen JB, Nielsen JE, BorkJensen J, Almstrup K, Sonne SB, Kjems J, Rajpert-De Meyts E, Leffers H. MicroRNA expression profiling of carcinoma in situ cells of the testis. Endocr Relat Cancer. 2012; 19:365-79. https://doi.org/10.1530/ERC-11-0271. [PubMed]

24. Bing Z, Master SR, Tobias JW, Baldwin DA, Xu XW, Tomaszewski JE. MicroRNA expression profiles of seminoma from paraffin-embedded formalin-fixed tissue. Virchows Arch. 2012; 461:663-68. https://doi.org/10.1007/ s00428-012-1325-9. [PubMed]

25. Vilela-Salgueiro B, Barros-Silva D, Lobo J, Costa AL, Guimarães R, Cantante M, Lopes P, Braga I, Oliveira J, Henrique R, Jerónimo C. Germ cell tumour subtypes display differential expression of microRNA371a-3p. Philos Trans R Soc Lond B Biol Sci. 2018; 373:20170338. https:// doi.org/10.1098/rstb.2017.0338. [PubMed]

26. Dieckmann KP, Spiekermann M, Balks T, Flor I, Löning T, Bullerdiek J, Belge G. MicroRNAs miR-371-3 in serum as diagnostic tools in the management of testicular germ cell tumours. Br J Cancer. 2012; 107:1754-60. https://doi. org/10.1038/bjc.2012.469. [PubMed]

27. Boellaard WP, Gillis AJ, van Leenders GJ, Stoop H, van Agthoven T, Dorssers LC, Dinkelman-Smit M, Boormans JL, Looijenga LH. Cellular origin of microRNA-371a-3p in healthy males based on systematic urogenital tract tissue evaluation. Andrology. 2019; 7:463-68. https://doi. org/10.1111/andr.12595. [PubMed]

28. Suh MR, Lee Y, Kim JY, Kim SK, Moon SH, Lee JY, Cha KY, Chung HM, Yoon HS, Moon SY, Kim VN, Kim KS. Human embryonic stem cells express a unique set of microRNAs. Dev Biol. 2004; 270:488-98. https://doi. org/10.1016/j.ydbio.2004.02.019. [PubMed]

29. Pfaff N, Moritz T, Thum T, Cantz T. miRNAs involved in the generation, maintenance, and differentiation of pluripotent cells. J Mol Med (Berl). 2012; 90:747-52. https://doi.org/10.1007/s00109-012-0922-z. [PubMed] 
30. Lee YJ, Ramakrishna S, Chauhan H, Park WS, Hong SH, Kim KS. Dissecting microRNA-mediated regulation of stemness, reprogramming, and pluripotency. Cell Regen (Lond). 2016; 5:2. https://doi.org/10.1186/s13619-0160028-0. [PubMed]

31. Radtke A, Dieckmann KP, Grobelny F, Salzbrunn A, Oing C, Schulze W, Belge G. Expression of miRNA-371a-3p in seminal plasma and ejaculate is associated with sperm concentration. Andrology. 2019; 7:469-74. https://doi. org/10.1111/andr.12664. [PubMed]

32. Pelloni M, Coltrinari G, Paoli D, Pallotti F, Lombardo F, Lenzi A, Gandini L. Differential expression of miRNAs in the seminal plasma and serum of testicular cancer patients. Endocrine. 2017; 57:518-27. https://doi.org/10.1007/ s12020-016-1150-z. [PubMed]

33. Rijlaarsdam MA, van Agthoven T, Gillis AJ, Patel S, Hayashibara K, Lee KY, Looijenga LH. Identification of known and novel germ cell cancer-specific (embryonic) miRs in serum by high-throughput profiling. Andrology. 2015; 3:85-91. https://doi.org/10.1111/andr.298. [PubMed]

34. Lobo J, Gillis AJ, Jerónimo C, Henrique R, Looijenga LH. Human Germ Cell Tumors are Developmental Cancers: Impact of Epigenetics on Pathobiology and Clinic. Int J Mol Sci. 2019; 20:E258. https://doi.org/10.3390/ijms20020258. [PubMed]

35. Looijenga LH, Kao CS, Idrees MT. Predicting Gonadal Germ Cell Cancer in People with Disorders of Sex Development; Insights from Developmental Biology. Int J Mol Sci. 2019; 20:E5017. https://doi.org/10.3390/ ijms20205017. [PubMed]
36. Salvatori DC, Dorssers LC, Gillis AJ, Perretta G, van Agthoven T, Gomes Fernandes M, Stoop H, Prins JB, Oosterhuis JW, Mummery C, Looijenga LH. The MicroRNA-371 Family as Plasma Biomarkers for Monitoring Undifferentiated and Potentially Malignant Human Pluripotent Stem Cells in Teratoma Assays. Stem Cell Reports. 2018; 11:1493-505. https://doi.org/10.1016/j. stemcr.2018.11.002. [PubMed]

37. Lembeck AL, Puchas P, Hutterer G, Barth DA, Terbuch A, Bauernhofer T, Pichler M. MicroRNAs as Appropriate Discriminators in Non-Specific Alpha-Fetoprotein (AFP) Elevation in Testicular Germ Cell Tumor Patients. Noncoding RNA. 2020; 6:2. https://doi.org/10.3390/ ncrna6010002. [PubMed]

38. Livak KJ, Schmittgen TD. Analysis of relative gene expression data using real-time quantitative PCR and the 2(-Delta Delta C(T)) Method. Methods. 2001; 25:402-08. https://doi.org/10.1006/meth.2001.1262. [PubMed]

39. Berney DM, Algaba F, Amin M, Delahunt B, Compérat E, Epstein JI, Humphrey P, Idrees M, Lopez-Beltran A, MagiGalluzzi C, Mikuz G, Montironi R, Oliva E, et al. Handling and reporting of orchidectomy specimens with testicular cancer: areas of consensus and variation among 25 experts and 225 European pathologists. Histopathology. 2015; 67:313-24. https://doi.org/10.1111/his.12657. [PubMed]

40. Jones TD, Ulbright TM, Eble JN, Cheng L. OCT4: A sensitive and specific biomarker for intratubular germ cell neoplasia of the testis. Clin Cancer Res. 2004; 10:854447. $\quad$ https://doi.org/10.1158/1078-0432.CCR-04-0688. [PubMed] 